\title{
Merging Comparative Law and Legal History : Towards an Integrated Discipline
}

\section{Pihlajamäki, Heikki Tapio}

2018-12

Pihlajamäki , H T 2018, ' Merging Comparative Law and Legal History : Towards an

pÿlntegrated Discipline ' , American Journal of Comparative Law , vol. 66 , no. 4 , pp. 733750 . https://doi.org/10.1093/ajcl/avy045

http://hdl.handle.net/10138/327775

https://doi.org/10.1093/ajcl/avy045

unspecified

acceptedVersion

Downloaded from Helda, University of Helsinki institutional repository.

This is an electronic reprint of the original article.

This reprint may differ from the original in pagination and typographic detail.

Please cite the original version. 
Heikki Pihlajamäki
University of Helsinki

Merging Comparative Law and Legal History: Towards an Integrated Discipline

I. Introduction: Why Do We Have Comparative Law and Legal History?

Comparative law has been in trouble for quite a while. In 2002, a leading comparatist described how the initial after-war success of the discipline eventually turned into stagnation. Much of the work done was still within the "Country and Western tradition," and interdisciplinary research remained exceptional. ${ }^{1}$ This was not the first report on the failures of comparative law, ${ }^{2}$ and certainly not the last. Although fifteen years have passed, the picture remains unchanged. Recently, another prominent representative of the field dismally portrayed comparative law's "doxa [as] long [...] committed to an understanding of the legal that can fairly be termed 'positivist-analytical' or 'positivist' tout court," and devoid of any cultural considerations. ${ }^{3}$

As comparatists, legal historians also struggle with questions of self-identity. Legal historians often feel the need to justify their discipline's existence as part of academic law curricula, and legal historians sometimes wonder whether they are historians, legal scholars, or both. Much like comparative law scholars, in many countries legal historians have felt their discipline institutionally threatened in recent decades. ${ }^{4}$ German legal historians often reminisce about the time when pure legal history chairs still existed (now they are all combined to positive law subject, usually civil law), and although in many countries the situation remains stable, the discipline hardly expands anywhere. Legal history differs from comparative law in one significant aspect. While comparatists are well organized at the international level, legal historians are not. The only truly international organization is the European Society of Comparative Legal History, whereas the annual or biannual meetings of American, British, and German legal historians act as substitute meeting forums for

\footnotetext{
${ }^{1}$ Mathias Reimann,'The Progress and Failure of Comparative Law in Second Half of the Twentieth Century," American Journal of Comparative Law 50 (2002), 671-697, 685. William Twining, Globalization and Legal Theory (2000), 184.

2 The literature is too large to list here. See, however, Twining (2000), 184-189; and Ugo Mattei, “An Opportunity Not to Be Missed: The Future of Comparative Law," American Journal of Comparative Law 46 (1998), 46.

${ }^{3}$ Pierre Legrand, "Jameses at Play: A Tractation on the Comparison of Laws," American Journal of Comparative Law 65:1 (2017), 1-132, 4.

${ }^{4}$ See Anthony Musson \& Chantal Stebbings (eds.), Making Legal History (Cambridge University Press, 2014).
} 
internationally inclined legal historians of other countries as well. Unlike in the field of comparative law (to paraphrase Pierre Legrand), there is no "institutional overdetermination" and little in the vein of learned societies, which would or could reward their members with "prizes, medals, ribbons, or parchments." 5 Thus, there is also less of an institutional shield to protect the field in times of trouble.

This article suggests a remedy for some of these problems. To deal with some of the challenges of both legal history and comparative law at once, I propose that the two disciplines merge. To substantiate the claim, I will first show how both disciplines share some of their history and with it, some of their major problems, but also potential for future success (II). I will then review some of the methodological challenges that legal history has faced over the past decades and discuss some of the solutions that legal historians have found to those problems (III). I will then proceed likewise with comparative law (IV). These stories have been told before, but they have not been linked to another. Section IV consists of suggestions of how the merger could be effectuated in both research and teaching. Section VI will conclude.

Of course, I am fully aware of the fact that, in recent years, innumerable attempts have been made to do something about comparative law's problems, and legal history's methodology has been widely discussed as well. I hope to be able to show that, although my suggestion may seem just as utopian as many of the previous proposals, the change is actually already well under way and, therefore, not any less than realistic.

\section{Common histories}

Besides contemporary problems, comparative law and legal history share some history. Albeit in different ways, both disciplines owe their existence to national, positivist legal scholarship. I will start with a few words on the history of legal history. In an impressive article, Joachim Rückert traces the roots of national legal histories to seventeenth-century figures, such as Hermann Conring in Germany, Claude Fleury in France, Matthew Hale in England, and Johan Stiernhöök in Sweden. National legal histories then developed as the dominant paradigm of the nineteenth and for the most part of the twentieth centuries. Karl Eichhorn with his massive four-volume Deutsche Staats- und Rechtsgeschichte (1808-1823) was the torchbearer in Germany. Pietro Luigi Albini with his

\footnotetext{
${ }^{5}$ Legrand (2017), 10.
} 
Elementi della storia del diritto in Italia followed suit in 1847, and Eduardo de Hinojosa in Spain with Historia general del derecho español in 1887. Frederick Pollock and Frederic Maitland's History of English Law before the Time of Edward I I-II (1898), Paul Viollet's Précis de l'histoire du droit français (Paris 1886), and Adhémar Esmein's Cours élémentaire d'histoire du droit français (1898) all operate in an overwhelmingly national framework as well. As Rückert explains, these modern - in the nineteenth-century meaning of the term - legal histories were also comprehensive in the sense of combining for the first time exterior and interior aspects of legal histories (dogmengeschichtlich). ${ }^{6}$

Legal historians provided an important slice of the nationalistic narrative, explaining how history had led national states to the particular situations in law they found themselves in. Because of the legitimizing tendency, much of the legal history became dogmengeschichtlich, explaining legal developments predominantly from the point of view of legislative development. While positive law and legal scholarship became overwhelmingly nationally oriented in the nineteenth century, internationally oriented counter-movements soon arose. Modern international law is largely a product of the late nineteenth and early twentieth centuries, and comparative law emerged almost simultaneously. ${ }^{7}$ It started early in the nineteenth century as a response to practical legislative needs, as “comparative legislation.” Some of the internationally minded German scholars also reacted against the national emphasis of Savigny's Historical School. These scholars included, for instance Paul von Feuerbach, Eduard Gans, Anton Thibaut, Karl Salomo Zachariä and Karl Joseph Mittermaier. Zachariä and Mittermaier even launched a journal, Kritische Zeitschrift für Rechtswissenschaft und Gesetzgebung (1829). ${ }^{8}$

Comparative legal scholarship acquired more academic overtones as the century wore on. Koskenniemi has explained how legal intellectuals, driven by "l'ésprit internationalité," in different parts of Europe began to envisage comparative legislation as a road towards universal justice (justice universelle). For these liberal jurists, law was a vehicle of progress in Europe and a tool to civilize the colonies. In the late nineteenth century, scholarship of comparative legislation included orientations that today would fall under comparative law, international law, comparative legal history, and legal anthropology. Soon enough, international legal scholars began to establish Journals with international taint: Revue historique de drot français et étranger (1855), Revue de

\footnotetext{
${ }^{6}$ Joachim Rückert, “The Invention of National Legal Histories," in Heikki Pihlajamäki, Mark Godfrey, Markus Dubber (eds.), The Oxford Handbook of European Legal History (Oxford: Oxford University Press 2018),

${ }^{7}$ See, Martti Koskenniemi, The Gentle Civilizer of Nations: The Rise and Fall of International Law 1870-1960 (Cambridge: Cambridge University Press, 2001).

${ }^{8}$ Leontin Constantinescu, Tratado de derecho comparado: introducción al derecho comparado (1981), 104-203.
} 
droit international et de legislation compare (1869), and Zeitschrift der vergleichende

Rechtswissenschaft (1878) were founded. At national and international level, professional associations of comparatists were established: The Association for the Reform and Codification of International law (later: the International Law Association) and Institut de droit international, both in 1873 as international societies, and as national associations, for example, Société de legislation compare (1869) in France, and Internationale Vereinigung für vergleichende Rechtswissenschaft und Volkswirtschaftslehre (1894) in Germany. ${ }^{9}$

The Conferences of the Société International de Droit Comparée in Paris (1900) and The Hague (1932) were turning points in the history of modern comparative law. ${ }^{10}$ The optimistic spirit was still strong at the Paris Conference. One of its main organizers, Raymond Saleilles, hoped in his opening address that comparative law would, when applied to legislation, doctrine, and judicial interpretation, could lead to a "droit commun de l'humanité civilisée." ${ }^{11}$ By the conference at The Hague, the optimism was clearly waning, not the least because of the experiences of the World War and because of Europe's stressing political situation, far from corresponding to the traditional liberal ideas of the internationalist legal scholar carrying the banner of comparative law.

After the Second World War, then, mainstream comparative law had little hope left in its possibilities of civilizing the world. The discipline declined into "country \& western" -style of scholarship, in which blackletter law of one country was compared to that of another. More often than not, both objects of comparison have been legal orders of Western countries (one representing common law, the other continental law), and in the majority of cases, the research deals with private law. When "differences and similarities" are detected and reported, not much else remains to say, as this type of comparative law does not place its finding into an historical, social, political, or economic context. This dominant paradigm was, in other words, a reflection of the dominant national-positivist paradigm in law. ${ }^{12}$

\footnotetext{
${ }^{9}$ See Koskenniemi (2001)); Martti Koskenniemi - Ville Kari, “The Emergence of International and Comparative Law (Nineteenth Century), in Heikki Pihlajamäki, Markus Dubber, Mark Godfrey (eds.), The Oxford Handbook of European Legal History (Oxford: Oxford University Press, 2018).

${ }^{10}$ See Konrad Zweigert and Hein Kötz, An Introduction to Comparative Law (Oxford: Clarendon Press, 1998), 2; René David - Camille Jauffret-Spinosi, Les grands systèmes de droit contemporains (2002) 2; Rodolfo Sacco, "One Hundred Years of Comparative Law," 75 Tulane Law Review, 1159.

${ }^{11}$ David S. Clark, "Nothing New in 2000--Comparative Law in 1900 and Today," 75 Tulane Law Review 871 (2001), 871-915, 876.

${ }^{12}$ As Ugo Mattei has argued, the dominance of the country \& western paradigm may well be understood within the context of the epoch's cold war politics. Ugo Mattei, "Cold War and Comparative Law: A Reflection on the Politics of Intellectual Discipline,” American Journal of Comparative Law 65:3 (1017), 567-607.
} 


\section{Challenges of Comparative Law}

Challenging the dominance of country \& western, competing ways of doing comparative law have emerged a long time ago. Yet, as far as mainstream comparative is concerned, Reimann and Legrand are right. A quick look at any of the major journals of the field will prove that surveys of "foreign law" (of the type "Recent developments of X law in Y") and traditional country \& western comparisons still fill their pages. Comparative law is also all but disappearing. Institutionally, however, comparative law has not been able to cash in the internationalization, Europeanization, and globalization trends of the recent decades. Surely, all kinds of comparisons have multiplied, ${ }^{13}$ and it has become fashionable to brand LL.M. programs and professorial chairs comparative whenever possible. Not only is it a question of fashion and trends: contemporary law and legal research absolutely benefit from a broader outlook than what the traditional positivist ways of teaching law have been able to offer. ${ }^{14}$ Indeed, comparative methods have spread to all legal disciplines with such force that the need for a separate discipline can truly be questioned. ${ }^{15}$ In most countries, therefore, comparative law as a discipline is not expanding the way one might have expected. Instead, it has retreated into a defensive position or is declining. ${ }^{16}$

When talking about the current problems of comparative law, we should, however, distinguish between its different orientations. Reimann identifies three. First, we have genuine comparisons, in which Object A is compared with Object B. It is here that one most often, although not necessarily, runs into the problems of blackletter comparison. Second, comparative law is thought to encompass studies which do not compare anything. One such variety is "foreign law," presentations of legal institutions or reforms of particular branches of law in another jurisdiction. A (Western) scholar may be specialized in, for instance, Russian or Japanese law. Representatives of foreign law research do not necessarily identify themselves with comparative law at all, but rather with "area studies".

\footnotetext{
${ }^{13}$ See Jennifer Hendry, "Contemporary Comparative Law: Between Theory and Practice, Review of Esin Örücü and David Nelken's Comparative Law: A Handbook", German Law Journal 9:12 (2008), 2253-2263.

${ }^{14}$ Look, for instance, at the various LL.M. programs with epithets such as "transnational," "global," and "international", that virtually all Dutch law faculties offer today. Probably the most avant-garde of them is the Global Law Bachelor, which Tilburg University offers. The program is admirably comparative all the way through and trains lawyers with truly international minds.

${ }^{15}$ Jaakko Husa, "Classification of Legal Families Today - Is it Time For a Memorial Hymn?" Revue internationale de droit comparé 2004, 11.

${ }^{16}$ Besides Reimann (2002, see e.g. Mathias M. Siems, "The End of Comparative Law," 2 Journal of Comparative Law, (2007), 133. To make it clear, let me emphasize that I am talking about comparative law as an independent, separate subject taught in law faculties and law schools, and practiced by specialists, which identify themselves primarily as "comparatists."
} 
Third, besides genuine comparisons and legal area studies, classifications of legal families or traditions have also developed into a subfield of their own. ${ }^{17}$ René David's division from the 1950s represents the first and most influential attempt at dividing the world's legal families pedagogically into groups. Others, such as Konrad Zweigert and Hein Kötz then continued with similar, slightly more fine-tuned classifications, which in the end did not essentially differ from each other. ${ }^{18}$ For some decades already, the classical classifications have been under attack of comparatists, and been accused of Western and private law bias. ${ }^{19}$ The legal cultures scholars offered to divide the world's legal systems according to their cultural aspects; that, however, did not produce very different divisions in practice. A myriad of competitive classifications have been offered, the most radical probably being Ugo Mattei's suggestion involving three dimensions of the $\operatorname{law}^{20}$ and Esin Örücü's classification based on the proportions of law originating from different legal orders. ${ }^{21}$ None of the competing classifications, however, has managed completely to overthrow the classic classifications. No wonder comparatists are growing tired of discussions on legal families.

The concept of legal culture has left a lasting mark on comparative law research. ${ }^{22}$ Sure enough, law emerges and changes in the world of complex cultural arrangements, and, from the point of view of other cultural products, law is in fact itself part of that context. If, however, legal cultures are understood as hermitically sealed entities, the concept becomes a problem. This is especially so if the concept of legal culture in explaining the reasons, mechanisms, and results of those exchanges. To do so, legal cultures must be understood as "porous" entities, which continuously negotiate with other legal orders on whether and what terms to accept their solutions and influences. ${ }^{23}$

Such research, of course, exists and in fact forms the fourth major strand of comparative law research - in addition to classical comparisons, foreign law, and legal families. Alan Watson first

\footnotetext{
${ }^{17}$ See Reimann 2002.

18 Zweigert and Kötz talked of "legal styles," according to which legal families were to be classified. The style consisted of elements such as historical development, mode of reasoning, typical legal institutions, the use of legal sources, and ideology; see Zweigert and Kötz (1992), 67-73; on legal families and the theories concerning them, Jaakko Husa, "Future of Legal Families," in Oxford Handbooks Online 2016.

19 See, for instance, P. G. Monateri, "Everybody’s Talking: The Future of Comparative Law," Hastings International and Comparative Law Review 21 (1998), 825-846; Andrew Harding, "Comparative Public Law: Some Lessons from South East Asia," in Andrew Harding and Esin Örücü (eds.), Comparativa Law in the $21^{\text {st }}$ Century (The Hague: Kluwer, 2002), 249-266; and Hein Kötz, “Abschied vom Rechtskreislehre?” Zeitschrift für Europäisches Privatrecht 6( 1998), 493-595.

${ }^{20}$ Ugo Mattei, "The Three Patterns of Law: Taxonomy and Law in the World's Legal Systems," The Americna Journal of Comparative Law 45:1 (1997), 5-44.

${ }^{21}$ Esin Örücü, "What is a Mixed Legal System: Exclusion of Expansion?” Electronic Journal of Comparative Law 12:1 (2008), 1-18.

${ }^{22}$ Most recently, see the discussion between James Gordley, James Whitman, and Pierre Legrand in American Journal of Comparative Law 65:1 (2017).

${ }^{23}$ See Annalise Riles , "Comparative Law and Socio-Legal Studies," in Mathias Reimann and Reinhard Zimmermann (eds.), The Oxford Handbook of Comparative Law (Oxford: Oxford University Press, 1996).
} 
brought the dynamic effect into discussion in 1974 with his hugely influential work on the legal transplants. ${ }^{24}$ After that, a powerful strand of comparative law discussions has revolved around how and why legal institutions, rules, decisions, and ideologies move, and how they change when they move. ${ }^{25}$ The idea of dynamism and movement, in fact, gives comparative law whatever explanatory force it may have today. Dynamic comparative law also necessarily involves an historical perspective and brings this type of comparative law extremely close to the most dynamic notions of legal history.

When talking about the problems of current comparative law, we should thus distinguish between the four research orientations of current comparative law. The connection of "foreign law studies" to comparative law is loose and at most informative, and one should probably not even try to force it into the methodology of comparative law. As for classification of legal families, they have become sincerely outdated, although some sort of classifications are needed for pedagogical reasons. That leaves us with two major orientations in the field: the "real comparisons" and the study of legal change and legal transfers. The real comparisons are no longer thinkable without legal history - and the study of legal change is its very essence. Does this mean that legal history is absorbing the viable parts of comparative law? I am afraid this is the case.

\section{Challenges of Legal History}

The transformations of legal history have partly flown from the same external circumstances as the changes in comparative law. The radicalism of the 1960s and 1970s reflected on the methods of legal history as well, just as it did on comparative law. Even though the link between political radicalism and the methodological changes are not direct, many legal historians became convinced of the need to view legal history in its wide cultural context, including the social and political surroundings. In Germany, serious research on the national socialist period and the history of public law began, and in the United States, the Critical Studies movement was spearheaded by legal historians such as Morton Horwitz and Robert Gordon. In Spain, similar contextual legal history was brought forward by Francisco Tomás y Valiente and in Finland, by Heikki Ylikangas - to name

\footnotetext{
${ }^{24}$ Alan Watson, Legal Transplants: An Appraoch to Comparative Law (Richmond: University Press of Virginia, 1974). ${ }^{25}$ Again, much of this discussion has revolved around terminology: whether to call the moving legal phenomena transplants, transfers, or translations - to name but a few examples; on the terminological debates, see Máximo Langer, "From Legal Transplants to Legal Translations: The Globalization of Plea Bargaining and the Americanization Thesis in Criminal Procedure," Harvard International Law Journal 45:1 (2004), 1-65.
} 
but a couple of examples. Although different from each other, all of these examples had to do with the felt necessity of ridding the discipline of the blackletter approach prevalent until then.

Another powerful trend in legal history has been its gradual breaking out of the national framework. This actually started in the early nineteenth century already with the so-called "universal legal history," represented by Eduard Gans, Karl Mittermaier, and others. The history of Spanish colonial law started with Ricardo Levene in the 1920, and modern history of medieval canon began with Stephan Kuttner in the 1930s. After the Second World War, European legal history then emerged through works of Francesco Calasso, Franz Wieacker, and Helmut Coing. Research into the socalled "reception" of Roman law became an integral part of European legal history. Conceptions as to how exactly the learned bodies of law - Roman and Canon - influenced European law in its different parts has changed, and no modern history of the phenomenon still exists. Nevertheless, European legal history with its emphasis on the reception has brought an element of dynamic comparative research into the field of legal history from early on. Recently, research has increasingly abandoned the traditional emphasis in the core areas of Europe - Italy, Germany, France - and more attention is being given to the fringe areas of European cultural space, such as Scandinavia, Eastern Europe, Latin America, and the former English colonies. ${ }^{26}$

Comparative legal history, as a brand used consistently, is a creation of the last one or two decades. The German Legal Historians' meeting in Regensburg in 1999 devoted one of its sessions to comparative legal history, but only in the 2010s did the "discipline" became clearly established. Again, the German Rechtshistorikertag, this time in Münster in 2010, discussed the relations between comparative law, legal history, and legal dogmatics. The European Society of Comparative Legal History was established in 2012. It now organizes biannual conferences and runs a journal called Comparative Legal History. ${ }^{27}$

It is only logical that legal history is now being expanded to the rest of the world as well through the so-called global legal history. In this modern global approach, whether one defines it, following Duve, as global-historical perspective into legal history, history of globalization of law, or a perspective into world history, movement and change stand out. As Thomas Duve puts it, "global legal history ... is especially interested in the reconstruction of the historical interaction between

\footnotetext{
${ }^{26}$ An example of what is being done is Heikki Pihlajamäki, Markus D. Dubber, and Mark Godfrey (eds.), Oxford Handbook of European Legal History (Oxford: Oxford University Press, 2018).

${ }^{27}$ Kjell Åke Modéer, "Abandoning the Nationalist Framework: Comparative Legal History,” in Heikki Pihlajamäki, Markus D. Dubber, and Mark Godfrey (eds.), Oxford Handbook of European Legal History (Oxford: Oxford University Press, 2018), 100 - 114, 110.
} 
actors and actants - often remote from one another - or even in the interaction between members of different historiographic communities." 28

Nevertheless, as in comparative law, also in legal history the mainstream is still nationally oriented while comparative, European, transnational, and other non-informed research programs remain exceptional. Again, any brief glance at a program of a major legal history conference in the United States, Britain, Germany, or France will confirm this. National legal histories cannot wholly be abandoned, given the fact that for a long time the national state has been and continues to be one of major norm-producing entities. However, the national state as a framework helps little is one is to understand something of law's cultural change. This applies just as well to the ancient world ${ }^{29}$ as it does to contemporary legal history. The most interesting and promising developments in legal history are precisely those which attempt at explaining and understanding local and regional legal change in larger contexts, and which even aim at "big structures, large processes, and huge comparisons" of law on a global scale. It is here that legal history, indeed, can have a large-scale impact.

\section{Merging the Disciplines: Comparative Legal History}

At what do the twin disciplines aim? What is their purpose in this world? To what audiences should they direct their messages? In its traditional mainstream form, comparative law cannot survive for much longer as a separate academic discipline and subject taught in law schools. Legal history has more hope, but hardly in its classic, national form. The twin disciplines both need to change, and to produce the change, they desperately need each other. In fact, they need one another so much that they ought to fuse into one discipline. I will try to concretize what this would mean in practice; both as far as teaching and research are concerned.

The teaching part falls easily into place. If a legal history teacher does not have endless hours at his or her disposal, the teacher will need to choose the themes they teach. This is the case even if a traditional run-through of Western legal history, from ancient Roman law to the European Union, is the basic choice. When choosing the themes, the teacher will probably take into account their

\footnotetext{
${ }^{28}$ Thomas Duve, "Global Legal History: A Methodological Approach", Oxford Handbooks Online (2017).

${ }^{29}$ See, for instance, Pierluigi Monateri, "Black Gaius: A Quest for the Multicultural Origins of the 'Western Legal Tradition," Hastings Law Journal 51:3 (2000), 479-556.
} 
relevance to contemporary law. The relevance may be of different kinds: it may relate to substance, method, or legal policy. If we teach Roman contract law, the subject directly relates to modern contract law. Without understanding Roman contracts, we do not fully understand why we have modern contracts. The medieval glossators offer a wonderful opportunity of explaining how the mind of the modern lawyer developed. Taking a closed body of sources (Corpus iuris civilis), the glossators set to explain away its internal inconsistencies, precisely the way a modern lawyer does with his or her set of legal sources. Examples of how the teaching of legal history may relate to legal policy usually come from contemporary legal history. ${ }^{30}$ For instance, a class on law in communist Russia or National Socialist Germany may serve as a reminder of how alert one should be of any threats to the rule of law. ${ }^{31}$

In other words, all legal history teaching ought to contribute to a deeper understanding of contemporary law - and I am talking about teaching legal history to future jurists. Otherwise, teaching legal history makes little sense and cannot be defended in the overly filled curricula of the law schools and faculties. In order to make legal history speak to the modern audience - such as law students - it needs to be comparative. All the examples above involve comparisons, either spatial, temporal, or both. Judging contemporary relevance itself automatically involves temporal comparison as it provokes the question: why is this important for today's world? Spatial comparisons demonstrate, classically, similarities and differences. Legal history cannot do without comparisons. Therefore, all relevant legal history is comparative legal history.

The same is true for comparative law: it also needs to demonstrate relevance. Blackletter comparisons seldom fulfill this criterion, because they developed in another world: one dominated by national jurisdictions and positive law. Instead, comparative methodology can offer tools to understand the rapid changes of modern law. These tools include concepts such as legal transplants, legal transfers, legal translations, or whatever we wish to call them, which explain the movement and change of legal institutions and ideas across the globe. The theories of legal cultures, families, or traditions offer a way of mapping the innumerable normative orders of the world in some sensible and understandable way. For the needs of a future legal professional, having such a map,

\footnotetext{
${ }^{30}$ I understand contemporary legal history as legal history of the nineteenth and twentieth centuries. For a comprehensive account, see Joachim Rückert, “Zeitgeschichte des Rechts: Aufgaben und Leistungen zwischen Geschichte, Rechtswissenschaften, Sozialwissenschaften, und Soziologie,” Zeitschrift der Savigny-Stiftung, Germanistische Abteilung 115 (1998), 1-85.

${ }^{31}$ According to Michael Stolleis, "The NS regime has [...] become a comparative point of reference that offers us the possilibity to condemn new rogue states and new forms of genocide." Michael Stolleis, "European Twentieth-Century Dictatorship and the Law," in Heikki Pihlajamäki, Mark Godfrey, Markus Dubber (eds.), The Oxford Handbook of European Legal History (Oxford: Oxford University Press, to be published in 2018).
} 
albeit rough and with some white spots on it, and an understanding of how and why the map may change is the most valuable thing comparative law can offer.

If, however, these objectives are taken seriously, comparative law cannot survive without legal history. A temporal element is in-built into the theory of legal change, and it is similarly in-built into the most advanced theories of legal cultures and legal traditions. More than anything, I am thinking about the way Patrick Glenn describes legal tradition as "network of information," for which "a changing presence of the past" is characteristic. ${ }^{32}$ No meaningful account of legal change or legal traditions (or whatever term we wish to use to denote the different groupings of the world's legal systems) can cope without a strong historical component.

For these reasons, it is obvious that the traditional separation of legal history and comparative law in university teaching is hopelessly outdated. Instead, the two should be combined into one course. ${ }^{33}$ Rearranging teaching is relatively easy, but how about scholarship? In the age of interdisciplinarity, speaking of merging academic disciplines may been superfluous. Why not, without further ado, just start doing interdisciplinary work? In fact, the most interesting legal historians and comparatists have already combined the disciplines a long time ago in their own works. Think of academics such as James Whitman, Lawrence Friedman, Reinhard Zimmermann, Matthias Reimann, or James Gordley. All of them have different profiles, and they understand the roles of legal history, comparative law, and legal cultures in different ways. However, depending on whom one asks, one will get different answers as to which discipline - legal history or comparative law - the scholars just mentioned should be categorized. They themselves probably do not even care. The list will grow much longer, if we include legal historians who habitually use comparative methods or comparatists who make use of historical arguments.

Still, one should not exaggerate the amount of integrated comparative-historical legal research: it would be an exaggeration to claim that the twin disciplines have been already united. More integration of the twin disciplines is desperately needed. This is not only because, as I believe, only this way can the research in this field offer something interesting to the academic community and society as a whole. My argument goes further. If understood in the modern way, the combined twin

\footnotetext{
${ }^{32}$ H. Patrick Glenn, Legal Traditions of the World (Oxford: Oxford University Press, 2018), 20-26.

${ }^{33}$ Space prevents me from entering into details of how the course could be organized. For one model (although not entirely based on merging of the twin disciplines), see Heikki Pihlajamäki, "When Small is Beautiful: Teaching Legal History in the European Periphery,” in Kjell Åke Modéer \& Per Nilsén (eds.), How to Teach European Comparative Legal History (Lund: Juristförlaget, 2011), 39-45.
} 
disciplines can perhaps develop into a true theory law, a jurisprudence which can help to understand large-scale contemporary developments in law. Combined, legal history and comparative law may indeed be able to offer tools for understanding what is going on in legal development at the national, regional, and global level. It may be carrying it too far to expect that this would bring back legal history's late-nineteenth-century glory as the leading social science or comparative law's role as the scholarship of global hope - but who knows. ${ }^{34}$

V. An Example of Merging Comparative Law and Legal History: The Case of Nordic Exceptionalism

I will now try to show what merging comparative law and legal history could mean in practice. The example stems from my on-going research on the legal roots of "Nordic exceptionalism." The example departs from the claim that we would do well to be able to explain why the Nordic societies have turned out particularly successful. The argument about "success" is essentially a comparative claim, because a society's success is always relative and measured against other societies. The claim has to do with comparative law, because - as my hypothesis goes - Nordic exceptionalism cannot be understood without taking law into consideration. This then leads to legal history because, as I argue, the part of the explanation that concerns law extends historically deep into the middle ages.

In global public imagery, the Nordic countries - Denmark, Finland, Iceland, Norway, and Sweden regularly stand out as particularly successful societies. We may indeed speak of Nordic exceptionalism when referring to this phenomenon, which has lifted the five countries of the northern European periphery to the vanguard of the most successful countries of the world. ${ }^{35}$ Success is, sure enough, a value-laden concept, but we have ways of measuring success. ${ }^{36}$ The Nordic societies are distinctively egalitarian, and they guarantee equal access to education at all levels. The Nordic peoples trust in each other and in their institutions, such as judiciary and

\footnotetext{
${ }^{34}$ James Whitman, "Bring Back the Glory!,” Rechtsgeschichte 4 (2004), 74-81.

${ }^{35}$ On the term, see Fochesato, Mattia \& Bowles, Samuel, "Nordic exceptionalism? Social democratic egalitarianism in world-historic perspective," Journal of Public Economics 127 (2015), 30-44 and the references therein.

${ }^{36}$ Undoubtedly, these can be culturally biased, but this is not the place to enter that discussion.
} 
police. ${ }^{37}$ Besides a high standard of living, the Nordic countries have the least corruption ${ }^{38}$ and extremely advanced gender politics. ${ }^{39}$ True, some countries have even higher per capita income (for instance Luxemburg, Switzerland, and Kuwait), and the general Nordic level of social welfare is no longer particularly generous in comparison to other Western European countries. ${ }^{40}$ The Nordic countries are not a paradise on earth ${ }^{41}$ but what makes them stand out is that so many favorable indicators coincide there. From the European and global perspective, it is vital to find out how this has been possible, and what have been the historical routes that have led to the present situation.

Law and legal change appear deeply embedded in many facets of Nordic exceptionalism. Many of these features are typical of well-developed liberal welfare states ruled by law. Understanding how the Nordic region came to score so well on so many points is therefore not possible, we may assume, without comparing the legal trajectories of the different parts of the Nordic. Two kinds of historical comparisons are in order. First, we need to compare the Nordic countries with each other to find out what such features they share which have led to the present situation. Second, the results of such a comparison need to be placed in the larger European and perhaps even global context.

Although the emphasis is historical, the results contribute essentially to understanding the functioning of today's legal orders, not only in the north of Europe but around the globe.

As political and religious histories are concerned, the state-of-the-art of research is reasonably clear. In Scandinavia, the fifteenth, sixteenth, and seventeenth centuries were periods of centralizing royal power and creation of the modern state. In both Sweden (including Finland) and Denmark (including Norway and Iceland), ${ }^{42}$ the royal authority increased from the late Middle Ages onwards and especially with the Reformation, although in Denmark it soon diminished in favor of the aristocracy. ${ }^{43}$ All this had consequences for law. Norway had a realm-wide law since 1274 (and 1276 for towns), and Iceland since 1281. The amount of royal legislation rapidly increased also in Denmark and

\footnotetext{
${ }^{37}$ See Rothstein, Bo, "Sweden: Social Capital in the Social Democratic State," in Robert D. Putnam (ed.), Democracies in Flux: The Evolution of Social Capital in Contemporary Society (Oxford: Oxford University Press, 2012).

${ }^{38}$ See the report of Transparency International, https://www.transparency.org/cpi2015\#results-table (accessed May 7 ,

2018); Charron, Nicholas, Victor Lapuente \& Bo Rothstein, Quality of Government and Corruption from a European Perspective: A Comparative Study of Good Government in EU Regions (Cheltenham, UK: Edward Elgar, 2013).

${ }^{39}$ See World Economic Forum's Global Gender Gap Index 2016.

${ }^{40}$ Gøsta Esping Andersen, The Three Models of the Welfare Capitalism (London: Polity, 1990).

${ }^{41}$ For a critical voice, see Samandaji, Nima, Scandinavian Unexceptionalism: Culture, Markets and the Failure of Third-Way Socialism (London: Institute for Economic Affairs, 2015).
}

\footnotetext{
${ }^{42}$ Unless noted otherwise, in this proposal "Sweden" normally refers to Finland as well. Similarly, "Denmark" includes Iceland and Norway. "Sweden proper" and "Denmark proper" refer roughly to present day Sweden and Denmark.

${ }^{43}$ Heikki Ylikangas, "The crown and the aristocracy in co-operation in Denmark and Sweden (the 'aristocraticregime')," in E. I. Kouri and Jens E. Olesen, The Cambridge History of Scandinavia, Vol. 2: 1520-1870 (Cambridge: Cambridge University Press, 2013), 101-132.
} 
Sweden from the late Middle Ages onwards. Sweden had general realm-wide laws from since the mid-fourteenth century. Although Denmark never acquired similar laws before the late seventeenth century, the differences between the provincial laws were limited, why Denmark in fact had a unified legal order since the thirteenth century. ${ }^{44}$

The Lutheran Reformation had wide-reaching consequences for the Nordic societies. It helped to bring about centralization of political power, now that temporal princes - in Scandinavia, kings became heads of the new Lutheran churches. The Reformation simplified the legal order by ridding it of a separate body of canon law and ecclesiastical courts. The appropriation of the ecclesiastical funds helped in setting up the modern state as well. The first hereditary kings striving for absolutism and governing more or less effectively were Gustav I Vasa in Sweden and Finland, and Christian III in Denmark, Norway, and Iceland. From the law's point of view, the Reformation changed many things. The ecclesiastical courts lost much of their jurisdiction and lost their connection to Rome. As for the law's substance and despite much continuity, a lot changed as well. Public education was created, poor relief became the responsibility of secular authorities, and - although mainly in Sweden and less in Denmark - criminal law drew harsh influence from Mosaic Law. ${ }^{45}$

However, existing histories - legal or other sort - fail to explain Nordic exceptionalism. This is the case for the following three reasons, which cannot be isolated from one another:

First, the standard narrative on Nordic exceptionalism allows no space for premodern history (understood here as the period before roughly the nineteenth century). This is a problem, because decisive developments, without which the modern developments cannot be understood, occurred at an early stage. These include a legislative wave all over Scandinavia in the thirteenth, fourteenth, and fifteenth centuries. The impact of the sixteenth-century Reformation and the legal changes it caused are another central feature, which is essential in understanding modern Nordic states. These changes include concentration of judicial and religious power, and the changes in the legal sources, as well as the shaping of Nordic law as fundamentally non-professional law.

Second, the existing accounts fail to apply comparative methods in identifying and explaining the differences in the legal histories of the Nordic countries. From the socioeconomic and political point of view, the Nordic countries varied substantially from one another. Without considering this, it is difficult to identify their shared features. In short, Denmark was, from early on, the most feudalized and, for a long time, politically the least concentrated of all. At the other end of the continuum, we

\footnotetext{
${ }^{44}$ Helle Vogt and Ditlev (eds.) The Danish medieval laws: the laws of Scania, Zealand and Jutland (London: Routledge, 2016).

${ }^{45}$ Heikki Pihlajamäki, “God's eternal and always just law”: Swedish criminal law and reformation. In Virpi Mäkinen (ed.), Law and the Lutheran Reformation (Leiden: Brill, 2006), 171-204.
} 
have Iceland, with Norway, Sweden, and Finland in between. These differences had considerable impact on the composition of law courts, as well. Comparisons are desperately needed here: comparisons both between the Nordic countries, and between Scandinavia and the rest of Europe.

Third, general and social historians, who have otherwise written on themes which bear on the roots of Nordic exceptionalism, hardly ever take law seriously. Instead, it has been often underestimated, ignored, and misunderstood. An excellent example is the recent Cambridge Handbook of Nordic History, the articles of which approach the subject from every thinkable aspect (politics, religion, economy, culture) - except law. From the 1970s onwards, Nordic historians have intensively used legal sources for studies in, for instance, historical criminology ${ }^{46}$ and matrimonial relations. ${ }^{47}$ All this has been important and has enhanced our knowledge of the workings of the law in different social circumstances, but the historical scholarship practiced by general historians has failed to recognize the per se importance of law. This has not been the case with the professional legal historians, amongst which the modern discipline of legal history has developed roughly from the 1970s and 1980s onwards - "modern" here meaning legal history that looks at law in its social, political, and economic context. Much work has been done on various aspects of law in the different Nordic countries, ${ }^{48}$ but none on Nordic exceptionalism

What would the role of law then be in the history of Nordic exceptionalism? My hypothesis is as follows. Despite different historical trajectories and socio-economic profiles in the medieval and early modern periods, the Nordic countries have created similar, successful welfare states. This is because their (largely lay-driven) legal orders have emerged simple, enabling legitimate and effective governance through law - a kind of proto-legalism already before the actual nineteenth-century Rechtsstaat.

We know that statutory law had since the Middle Ages gained an important position in the Nordic realms. The array of legal sources grew almost equally versatile during the sixteenth and seventeenth century, as was the case in the regions of Western and Southern Europe. Because of the simple social

\footnotetext{
${ }^{46}$ Heikki Ylikangas, Puukkojunkkareitten esiinmarssi: väkivaltarikollisuus Etelä-Pohjanmaalla 1790-1825 (Helsinki: WSOY, 1976); Eva Österberg and Dag Lindström, Crime and social control in medieval and early modern Swedish towns (Uppsala: University of Uppsala, 1988); Anu Koskivirta, "Sisäinen vihollinen": henkirikos ja kontrolli PohjoisSavossa ja Karjalassa Ruotsin vallan ajan viimeisinä vuosikymmeninä (Helsinki: Yliopistopaino, 2001).

${ }^{47}$ Carlsson, Lizzie, "Jag giver dig min dotter": Trolovning och äktenskap i den svenska kvinnans äldre historia I - II, (Lund: Institutet för rättshistorisk forskning, 1965 \& 1972)

${ }^{48}$ Lars Björne, Den nordiska rättsveteskapens historia I-IV (Stockholm: Institutet för rättshistorisk forskning, 1995 2007); Jørn Øyrehagen, Sunde, Speculum legale - Rettsspegelen: Ein introduksjon til den norske rettskulturen si historie i eit europeisk perspektiv (Bergen: Fagbokforlaget, 2005); Mia Korpiola, Between Betrothal and Bedding: Marriage Formation in Sweden 1200-1600 (Leiden: Brill, 2009).
} 
structure of the northern societies, the legal sources competing with royal statutory law - learned ius commune, feudal law, town law, and customary law - never gained as much importance there as elsewhere. ${ }^{49}$ The centralized royal power channeled features of these competing sources straight into the early modern Nordic laws, which were based on the medieval laws and summarized the legal changes of the sixteenth and seventeenth centuries. The Danish Law of the Realm of 1683, together with its Norwegian and Swedish counterparts (1687 and 1734, respectively), set the course for the eighteenth century.

The Nordic laws of the realm were all in some ways products of the centralized state with weak estates. They wiped out much of the competing sources of law, which had begun to rise in the sixteenth and seventeenth century. The laws of the realm were royal legislation and accepted by the estates. These laws left little room customary law, town laws, patrimonial courts, or Roman law although the weight of these competing legal sources differed slightly from one Nordic country to another. To be sure, some important areas of law were left out of these compilations, such as administration, financial, and commercial regulation - all the areas of law which at the time were grouped under the heading of ius politiae, "police law". ${ }^{0}$ The laws of the realm contained only such rules that were thought to be immutable and unchanging. In addition, it seems that the court practice gained in all countries during the eighteenth century.

The above is, however, a background sketch only, and the actual research is far from done. Many questions remain. Although written law was more important than the other sources, it was never the sole source of law. The significance of customary law, especially, requires extra attention and archival studies: did it gain ascendance in Norway and Denmark during the eighteenth century as the Laws of Realm grew older? How about Sweden? If so, was customary law "wild” (on the term, see Garré 2005) or was of the kind which had been ratified by high court practice? How does the rise of police law relate to this? How different were the early modern Nordic laws from the Enlightenment codes, or from each other? To what extent were the codes truly followed, and to what extent did other sources prevail? The only way to find out is archival research.

The research agenda described above departs from national entities. They are, however, a starting point only. The study then will present Nordic comparative legal history as a series of partly overlapping contexts, changing centers, and peripheries, within with legal transplants move and,

\footnotetext{
${ }^{49}$ Heikki Pihlajamäki,"Statute Law in Early-Modern Swedish Criminal Trials - A Case of Pre-Positivism," in Georges Martyn, Anthony Musson and Heikki Pihlajamäki (eds.), in From the Judge's Arbitrium to the Legality Principle: Legislation as a Source of Law in Criminal Trials (Berlin: Duncker \& Humblot, 2013).

${ }^{50}$ On Swedish police law, see Toomas Kotkas, Royal Police Ordinance in Early Modern Sweden: The Emergence of Voluntaristic Understanding of Law (Brill: Leiden, 2014).
} 
while moving, change and adapt to new circumstances. ${ }^{51}$ For example, think of sixteenth-century Finland: after the Reformation, Finnish legal life received impulses not only from Sweden, but directly from Germany as well. Legal ideas and normative models - such as theories of proof or punishment - were adapted to Nordic circumstances, and the "end product" often seemed quite different from when compared to what is was in its place of origin. ${ }^{52}$ Understood this way, and with the help of comparative law's best methods, legal history becomes a dynamic enterprise.

\section{Conclusion}

This Article suggests that legal history and comparative law ought to be merged into one discipline. The twin disciplines are both products of the same period, the late nineteenth century, when they were formed as results of the positivist legal scholarship gaining dominance then. They are, to be sure, opposite sides of the coin. Mainstream legal history was, from early on, a humble servant of positivism, whereas comparative law formed an antithesis to it. Nevertheless, neither of the twin disciplines would exist as such, were it not for the emergence of national legal positivism on both sides of Atlantic.

The largest obstacle in the way of merging the twin disciplines is perhaps the fact they, as all scholarly disciplines, are also social communities. They have their own associations, conferences, and journals, which uphold the field's traditions, identities and internal discussions. These discussions are not always open to neighboring disciplines. This is clearly the case with the twin disciplines as well, but in comparative law considerably more than in legal history. Although a change may be under way, most scholars still like to identify themselves as "comparatists" or "legal historians."

\footnotetext{
${ }^{51}$ As for the legal history of early modern Scandinavia, centers and peripheries are not easy to define, and the borders between them did not respect modern state borders. As for Sweden, the surroundings of Stockholm and Turku (in Western Finland) formed a center, as did to lesser extent other cities with high courts (Jönköping, Tartu). Historically, Swedish Livonia, with its capital and high court in Tartu, was much closer to the German cultural sphere than Stockholm. Norway was not a periphery of Denmark until from the 1590s onwards, and foreign influences starting reaching Norway independently of Denmark again in the mid-eighteenth century.

52 Typically, Germany, see Heikki Pihlajamäki, "Gründer, Bewahrer oder Vermittler? Die nationalen und internationalen Elemente im Rechtsdenken des Olaus Petri,“ in Jörn Eckert and Kjell A. Modéer (ed.s), Juristische Fakultäten und Juristenausbildung im Ostseeraum (Stockholm: Institutet för rättshistorisk forskning, 2004), 29-38.
} 
For lack of a better term, I would for now just call the approach combining the twin disciplines legal history. The term "comparative legal history" is awkward as it includes the term "comparative" which is really a reminiscence of the time when mainstream comparative law was still literally comparative. The term "comparative" may also, for some, imply that a "noncomparative" legal history is a discipline apart, and that there would be something like "noncomparative legal history" - which is not intended. The new combined discipline would hopefully marginalize outdated ways of doing scholarship in both mother disciplines. It would marginalize the kind of legal history, which seems unconscious of the world outside national boundaries and of international contexts, and it would marginalize the kind of comparative law, which is made without reference to the historical paths, which have led the present situation. What I do mean is that research topics dealing solely with local or national problems would not be worthy of research; on the contrary, they can be extremely valuable and important for the both local, national, and international readerships and communities. Instead, my emphasis is on the consciousness of international and transnational contacts and links - whenever applicable. In that way, all legal history is comparative. 